Politik Ekonomik Kuram 2018, Cilt 2(1), 103-123

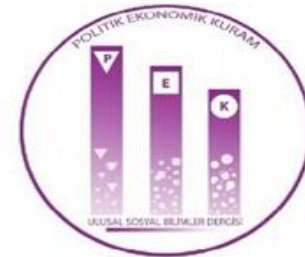

Politik Ekonomik Kuram Dergi Web Sitesi: http://dergipark.gov.tr/pek

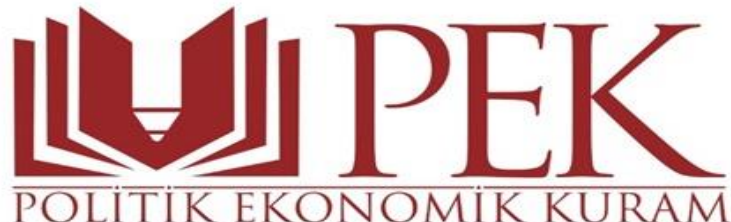

Cilt 2(1) 2018

\title{
Türkiye'de Enerji Tüketimi ve Cari Açığın Ekonomik Büyüme Üzerine Etkisi
}

Rabia EFEOĞLU ${ }^{1}$

Ceren PEHLIVAN ${ }^{2}$

\section{Makale Bilgileri}

Makale Geçmişi:

Makalenin Yüklendiği Tarih: 24.04.2018

Makalenin Kabul Edildiği Tarih: 04.05.2018

Jel Kodlar1: O44, O42, O47

Anahtar Kelimeler: Enerji Tüketimi, Ekonomik Büyüme, Cari Açık

\footnotetext{
${ }^{1}$ Arş. Gör. Niğde Ömer Halisdemir Üniversitesi İktisadi ve İdari Bilimler Fakültesi Uluslararası Ticaret ve Lojistik Yönetimi Bölümü rabia.efeoglu@ohu.edu.tr

2 Doktora Öğrencisi İnönü Üniversitesi İktisadi ve İdari Bilimler Fakültesi İktisat Bölümü pehlivanceren23@hotmail.com
} 
Efeoğlu R., Pehlivan C.. (2018), “Türkiye'de Enerji Tüketimi ve Cari Açı̆̆ın Ekonomik Büyüme Üzerine Etkileri” Politik Ekonomik Kuram, Cilt 2(1)

\title{
Özet
}

Sosyoekonomik kalkınma göstergelerinden biri olan enerji tüketimi kalkınma için önemli bir girdi olarak kabul edilmesinin yanı sıra ekonomik büyüme üzerinde önemli bir rol oynamaktadır. Çalışmanın temel amacı, Türkiye'de nihai enerji tüketimi ile ekonomik büyüme ve cari açık arasındaki ilişskinin belirlenmesidir. Bu amaca yönelik olarak 1987-2016 dönemine ilişkin veriler kullanılarak Johansen Eşbütüleşme, Etki tepki analizi, Granger ve TodaYamamato Nedensellik testleri yapılmıştır. Elde edilen sonuçlara göre, enerji tüketimi, cari açık ve ekonomik büyüme arasındaki uzun dönemli ilişkilerin varlığı Johansen Eşbütünleşme testi ile belirlenmiş, Granger Nedensellik testi yardımıyla GSYİH'dan cari açığa, enerji tüketiminden de GSYİH ve cari açığa doğru tek yönlü bir nedenselliğin olduğu; TodaYamamato Nedensellik testi ile de cari açıtan GSYİH 'ya ve enerji tüketiminden de GSYİH 'ye doğru bir nedenselliğin olduğu görülmüştür.

Anahtar Kelimeler: Enerji Tüketimi, Ekonomik Büyüme, Cari Açık

\section{The Effects Of Energy Consumption And Current Deficit On Economic Growth In Turkey}

\begin{abstract}
Energy consumption, one of the indicators of socio-economic development, plays an important role in economic growth as well as being accepted as an important input for the development. The main purpose of the study, is to determine the relationship between final energy consumption in Turkey and economic growth and the current account deficit. Johansen Cointegration, Impact response analysis, Granger and Toda-Yamamato Causality tests were conducted using the data for the period of 1987-2016 for this purpose. According to the results obtained, the existence of long-term relationships between energy consumption, current account deficit and economic growth is identified by the Johansen Cointegration test, it was found that there is a one-way causality from GDP to current account deficit and from energy consumption to GDP and current account deficit through Granger Causality test; it has been seen with the Toda-Yamamato Causality test that there is a casuality from the current account deficit to GDP and from energy consumption to GDP.
\end{abstract}

Keywords: Energy Consumption, Economic Growth, Current Account Deficit 


\section{Giriş}

İnsanlık tarihinin en önemli ihtiyaçlarından biri haline gelen enerji, ülke ekonomilerinde ve ülke ekonomilerinin gelişme sürecinde önemli bir yer tutmaktadır (Yanar ve Kerimoğlu, 2011). Gerek sanayi hammaddesi olması gerekse de 1sıtıcı ve çevirici güç olarak kullanılması nedeniyle enerji sektörü hızla gelişmektedir (Demirbaş vd., 2009) .

Enerji kullanımı ülkelerin ekonomik gelişme süreçlerinde büyük bir öneme sahiptir. Bu önem, enerji sektörünün ekonomik büyüme üzerinde rol oynaması ve ekonominin diğer sektörleriyle olan yapısal bağ lılığı dolayısıyla ortaya çıkmaktadır. Bu nedenle de enerji gereksiniminin nüfus artışı ve ekonomik gelişmenin yanı sıra düşük maliyetlerle de sağlanması büyük önem taşımaktadır (Esmer, 1996).

Sosyo-ekonomik kalkınma göstergelerinden biri olan enerji tüketimi son 20-30 yılda ülkelerin ekonomik gelişmelerine paralel olarak hızla artış göstermektedir (Güvenek ve Alptekin, 2010). Enerji tüketimi, ekonomik büyüme ve cari açık Türkiye'de enerji politikalarının oluşturulmasında oldukça önem arz eden değişkenlerdir.

Günümüzde enerji tüketimi ve ekonomik büyüme ilişkisini ortaya koymaya çalışan pek çok çalışma bulunmaktadır. Bu ilişki çalışmaların bir kısmında sadece ülke bazında ele alınırken diğer bir kısmında birden fazla ülke ele alınarak karşılaştırma yapma yoluna gidilmiştir. Ancak literatür taramasında Türkiye'de enerji tüketimi ve ekonomik büyüme arasındaki ilişkileri inceleyen birçok akademik çalışmaya rastlanılmasına rağmen, cari açık konusunu içeren çok fazla çalışma görülmemiştir.

Çalışmanın temel amacı Türkiye'de nihai enerji tüketimi, ekonomik büyüme ve cari açık arasındaki ilişkinin belirlenmesidir. Bu kapsamda çalışmada enerji tüketimi ve ekonomik büyüme arasındaki ilişkiye değinilerek; Türkiye'de enerji tüketimi, ekonomik büyüme ve cari açık ilişkisi ile Türkiye'nin enerji görünümü incelenmiştir. Daha sonra bu veriler kullanılarak ekonometrik analizler gerçekleştirilmiştir. Çalışmanın sonunda araştırma bulgularından hareketle sonuç sunulmuştur. 
Efeoğlu R., Pehlivan C.. (2018), “Türkiye'de Enerji Tüketimi ve Cari Açı̆̆ın Ekonomik Büyüme Üzerine Etkileri” Politik Ekonomik Kuram, Cilt 2(1)

\section{Enerji Tüketimi ve Ekonomik Büyüme Arasındaki İlişki}

Günümüzde üretim sürecinde temel girdiler arasında kabul edilen enerji faktörü ekonomik ve sosyal kalkınmanın gerçekleştirilmesi açısından önem taşımaktadır (Mucuk ve Uysal, 2009). Enerji; mal ve hizmet üretimi, konut, ulaşım vb. gibi birçok alanda sürekli bir ihtiyaç niteliğine bürünerek insanoğlunun iktisadi hayatı boyunca vazgeçilemez yapıtaşlarından biri olmuştur. Enerjiye olan talebin sürekli artması, refah artışları ve büyümeye paralel olarak artış şeklinde gözlemlenmektedir. Ekonomik büyüme ve enerji tüketimi arasında önemli bir bağ bulunmakta ve bu iki değişken karşılıklı olarak birbirini etkilemektedir (Özçağ, 2015).

Ülkelerin ekonomik büyüme, sosyal gelişme ve yaşam standartlarının yükseltilmesinde ciddi bir rol oynayan enerjinin girdi olarak öneminin artması 1973-1974 ve 1978-1979 petrol fiyatları artışlarına kadar gitmektedir. Bu dönemde enerji bağımlılı̆̆ının ne kadar fazla olduğu da ortaya çıkmıştır. Bu sıkıntılı sürecin aşılmasıyla birlikte hem gelişmiş hem de gelişmekte olan ülkeler açısından enerji tüketimi ve büyüme ilişkisi göz ardı edilemez hale gelmiş, ülkeleri alternatif enerji kaynakları aramaya zorunlu kılmıştır (Güvenek ve Alptekin, 2010).

Enerji kullanımının artmasında endüstri devrimi sonucu makineleşme ve sanayi sektörünün hız kazanması da etkili olmuştur. Nitekim özellikle 1980 sonrasında Türkiye'de nüfusun ve sanayileşmenin hız kazanması ile enerji tüketimi hızla artış göstermiştir. $\mathrm{Bu}$ dönemde ekonomik olarak gelişme gösteren enerji daha fazla kullanılmaya başlamıştır (Yanar ve Kerimoğlu, 2011).

Ekonominin genel yapısındaki söz konusu değişim daha fazla enerji kullanımını gerektirdiği için özellikle petrol, doğal gaz ve kömür türü fosil yakıtlara olan talep de yükselmiştir (Mucuk ve Uysal, 2009).

\section{Türkiye’de Enerji Tüketimi, Ekonomik Büyüme ve Cari Açık İlişkisi}

Enerji tüketimi, ekonomik büyüme ve cari açık arasındaki ilişki 1970 petrol krizine dayanmaktadır. 1970 petrol krizi ile enerji fiyatları artış göstermiş, enerji tüketimi petrol fiyatlarını artırmanın yanında cari açığı da artırıcı etki yapmıştır. Ekonomik büyüme üretim artışıyla sağlanır. Bu ise sermayenin oluşturulmasını gerektirir. Türkiye sermaye mallarını ithal 
Efeoğlu R., Pehlivan C.. (2018), “Türkiye'de Enerji Tüketimi ve Cari Açı̆̆ın Ekonomik Büyüme Üzerine Etkileri” Politik Ekonomik Kuram, Cilt 2(1)

ettiğinden söz konusu durum cari açı̆̆ın artmasına yol açmaktadır. Türkiye, üretimin sağlanması açısından önemli girdilerden biri haline gelen enerjide \%70 oranında dişa bağımlıdır. Türkiye'de enerji tüketimi sektörlere göre farklılık gösterdiğinden bu tüketimler ekonomik büyüme ve cari açık ilişkilerini de meydana getirmektedir (Yanar ve Kerimoğlu, 2011).

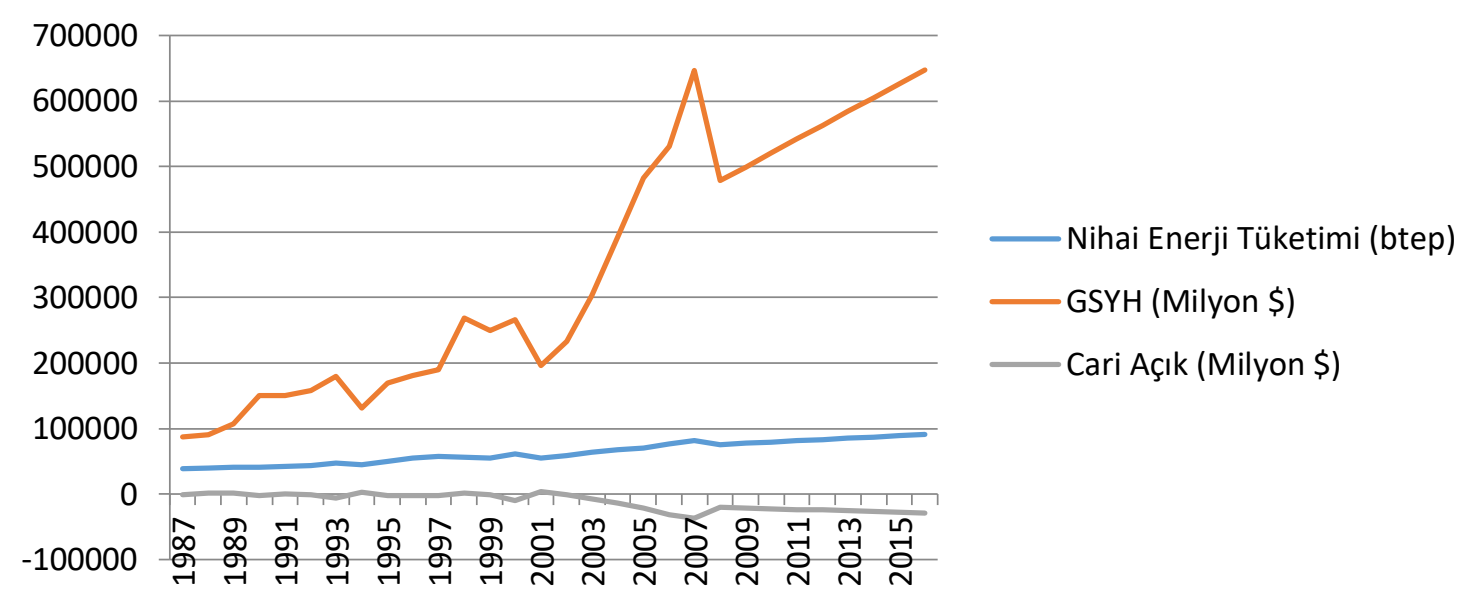

Kaynak: ETKB,2015; Dünya Bankası, 2015; TCMB, 201

\section{Grafik 1. Türkiye’de Enerji Tüketimi, Ekonomik Büyüme ve Cari Açık İlişkisi}

Grafik 1'e göre Türkiye'de bu anlamda Enerji ve Tabii Kaynaklar Bakanlığı verilerine bakıldığında enerji tüketimi genel olarak 1987'den itibaren artış göstermiş, 1987'de 38695 btep olan enerji tüketiminde 2016'da 104576 btep'e kadar artış meydana gelmiştir. Türkiye Cumhuriyet Merkez Bankası verilerine göre 1987'de -806 milyon \$ olan cari açı̆̆ımız 2016 yılı itibariyle -33137 milyon \$ olmuştur. GSYH değerlerine baktı̆̆ımız zaman Dünya Bankası verilerine göre 1987 'de 87172 milyon \$ iken 2016'te 863711 milyon \$'a kadar artış meydana gelmiştir. Kısaca enerji tüketimimiz artış göstermekte, cari açığımız negatif seyir izlerken GSYH değerlerimizde artış meydana gelmektedir. Aynı zamanda kriz dönemlerinden önce cari açı̆̆ın artışı da söz konusu olmuştur.

Dünya Enerji Konseyi Türk Milli Komitesi 2014 Raporunda Türkiye'nin dışa bağımlılı̆̆ 2009 itibari ile \% 71 olarak belirtilmekte iken, 2015'de \%68 ve 2020'de $\% 70$ seviyelerinde enerji talebi ile karşılaşacağı tahmin edilmektedir (Dünya Enerji Konseyi Türk Milli Komitesi, 2008).

Heinrich Böll Stiftung Derneği Türkiye'nin yıllık enerji tüketiminin \%4-5, yıllık elektrik tüketiminin de \%7-8 oranında artış gösterdiğini belirtmektedirler. Bu oranların dünya enerji 
Efeoğlu R., Pehlivan C.. (2018), “Türkiye'de Enerji Tüketimi ve Cari Açı̆̆ın Ekonomik Büyüme Üzerine Etkileri” Politik Ekonomik Kuram, Cilt 2(1)

gereksiniminin iki, üç katına tekabül ettiğini de vurgulamaktadırlar (Heinrich Böll Stiftung Derneği, 2008).

Türkiye'de artan enerji tüketiminden dolayı enerji ithalatında artışlar ortaya çıkmaktadır. Enerji tüketimdeki artışlar büyümeye bu da cari açığa neden olmaktadır (Yanar ve Kerimoğlu, 2011).

\section{Literatür}

Enerji tüketimi ile ekonomik büyüme arasındaki ilişki uzun zamandır akademik çalışmalarda inceleme konusu olmuştur. Bununla birlikte literatür taramasında enerji tüketimi ile cari açık ilişkisini doğrudan konu edinen çok fazla sayıda akademik çalışmaya rastlanmamıştır.

Akinlo (2008) yaptığ 1 çalışmada, 11 Sahra Altı Afrika'da ülkesi için Sınır Testi ve Granger Nedensellik testlerini kullanarak enerji tüketimi ile ekonomik büyüme arasındaki ilişkiyi incelemiştir. Sınır testi sonucunda 7 ülkede (Cote D’Ivoire, Gambiya, Gana, Kamerun, Senegal, Sudan ve Zimbabwe) ekonomik büyüme ile enerji tüketiminin eşbütünleşik olduğunu; Granger Nedensellik testi sonucunda ise Gambiya, Gana ve Senegal'de çift yönlü bir nedensellik ilişsisi elde etmiştir. Sudan ve Zimbabve'de ekonomik büyümenin, enerji tüketiminin Granger nedeni olduğunu Kamerun ve Cote D’Ivoire'da herhangi bir nedensellik ilişkisi olmadığı sonucuna varmıştır.

Altınay ve Karagöl (2004) ise Türkiye'de enerji tüketimi ve reel GSYİH arasındaki ilişkiyi 1950-2000 dönemi için Zivot ve Andrews (1992) ve Perron (1997) sinamalarıyla analiz etmişlerdir. Sonuç olarak, enerji tüketimi ve GSYİH arasında nedensellik ilişkisi olmadığı sonucuna varmışlardır.

Apergis ve Payne (2010) çalışmasında, 1980-2005 döneminde Güney Amerika ülkelerinde enerji tüketimi ve ekonomik büyüme ilişkisini analiz etmiştir. Enerji tüketiminden ekonomik büyümeye doğru bir nedensellik ilişkisinin bulunduğu sonucuna ulamışlardır.

Chen vd. (2006), 1971-2001 dönemi için 10 Asya ülkesinde ekonomik büyüme ile elektrik tüketimi ilişkisini analiz etmiştir. Kısa dönemde ekonomik büyümeden elektrik tüketimine doğru tek yönlü, uzun dönemde ise iki yönlü bir nedensellik ilişkisinin bulunduğunu belirtmişlerdir. 
Efeoğlu R., Pehlivan C.. (2018), “Türkiye'de Enerji Tüketimi ve Cari Açı̆̆ın Ekonomik Büyüme Üzerine Etkileri” Politik Ekonomik Kuram, Cilt 2(1)

Cheng (1997), üç Latin ülkesinde (Brezilya, Meksika ve Venezüella) Granger Nedensellik testini kullanarak enerji tüketimi ve ekonomik büyüme ilişsisini incelemiştir. Meksika ve Venezuela için enerji tüketimi ve ekonomik büyüme arasında bulunamazken Brezilya için enerjinin ekonomik büyümeye sebep olduğu sonucuna varılmıştır.

Chontanawat ve Pierse (2008) yaptığ 1 çalışmada, 30 OECD ve 78 OECD dışı ülkeyi ele alarak toplam enerji tüketimi ve GSYİH ilişkisini incelemiş, OECD ülkelerinde OECD üyesi olmayan ülkelere göre iki yönlü nedensellik ilişkisinin daha yaygın olduğu sonucuna varmıştır.

Demirbaş vd (2009)'da, Türkiye'de 1984-2008 dönemi için ADF, eşbütünleşme analizleri, VECM analizlerini kullanarak petrol fiyatları ile cari açık ilişkisini incelemiş, petrol fiyatlarında meydana gelen artışın cari açığı artırıcı etki yaptığı sonucuna ulaşmışlardır.

Ebohon (1996), Tanzanya ve Nijerya için enerji tüketimi ve ekonomik büyüme arasındaki ilişkiyi incelemiş, her iki ülkede de çift yönlü bir nedensellik ilişkisi olduğu sonucuna varmıştır.

Glasure ve Lee (1997), 1961-1990 döneminde Güney Kore ve Singapur için eşbütünleşme, hata düzeltme modelleri ve Granger Nedensellik testi kullanarak enerji tüketimi ve GSYİH ilişkisini test etmişlerdir. Güney Kore için GSYİH ve enerji tüketimi arasında bir nedensellik ilişkisi bulunamazken Singapur için enerji tüketiminden GSYİH'ya doğru tek yönlü bir nedensellik ilişki bulunmuştur.

Güvenek ve Alptekin (2010), 25 OECD üyesi ülke için Panel Data Analizi kullanarak nihai enerji tüketimi ve ekonomik büyüme arasındaki nedensellik ilişkilerini tahmin etmiş, söz konusu ülkelerde ekonomik büyüme ve enerji tüketimi arasında dikkate değer bir ilişki bulunduğu sonucuna varmıştır.

Hondroyiannis vd. (2002), 1960-1996 dönemine ait verilerle Yunanistan'da enerji tüketimi ve ekonomik büyüme arasındaki ilişkiyi vektör hata düzeltme modeli kullanarak analiz etmiştir. Elde edilen sonuçlara göre değişkenler uzun dönemde eşbütünleşik olup enerji tüketiminin ekonomik büyümenin belirlenmesinde önemli bir role sahip olduğunu ortaya koymuştur. 
Efeoğlu R., Pehlivan C.. (2018), “Türkiye'de Enerji Tüketimi ve Cari Açı̆̆ın Ekonomik Büyüme Üzerine Etkileri” Politik Ekonomik Kuram, Cilt 2(1)

Hossain (2011), 1971-2007 dönemi için yeni sanayileşmiş ülkelerde karbondioksit emisyonları, enerji tüketimi, ekonomik büyüme, ticari açıklık ve kentleşme ilişkilerini incelemiştir. Çalışmada, ekonomik büyümeden enerji tüketimine ve ticari açıklıktan da ekonomik büyümeye doğru kısa dönemli bir nedensellik ilişkisi bulunduğu sonucuna ulaşılmıştır.

Jobert ve Karanfil (2007), Türkiye'de enerji tüketimi ile gelir arasındaki ilişkiyi 1960-2003 dönemi için analiz etmişlerdir. Johansen Eşbütünleşme testi, reel GSMH ile enerji tüketimi arasında uzun dönemde herhangi bir ilişkinin bulunmadığını göstermiştir.

Kar ve Kınık (2008) tarafından yapılan çalışmada Türkiye'de 1975-2005 dönemine ilişkin toplam elektrik tüketimi, sanayi elektrik tüketimi ve mesken elektrik tüketimi ile ekonomik büyüme arasındaki ilişsi incelenmiştir. Johansen Eşbütünleşme testi ile toplam, sanayi ve mesken elektrik tüketimleri ile ekonomik büyüme arasındaki uzun dönemli ilişki olduğu, Vektör Hata Düzeltme Mekanizması (VECM) yardımıyla da nedenselliğin yönünün elektrik tüketimlerinden ekonomik büyümeye doğru olduğu görülmüştür.

Karagöl vd. (2007), Türkiye'de ekonomik büyüme ile elektrik tüketimi ilişkisini 1974-2004 dönemi için Sınır Testi Yaklaşımı ile analiz etmişlerdir. Eşbütünleşme testi yapılarak kısa dönemde değişkenler arasında pozitif, uzun dönemde ise negatif çıkmıştır.

Lee (2005), 18 gelişmekte olan ülke için 1975-2001 döneminde enerji tüketimi ve GSYİH ilişkisini analiz ederek enerji tüketiminden GSYİH’ya doğru kısa ve uzun dönemde bir nedensellik ilişkisinin olduğu bulmuştur.

Lise ve Montfort (2007), 1970-2003 dönemi için enerji tüketimi ile GSYİH ilişkisini eşbütünleşme ve vektör hata düzeltme modeli analizleri ile test etmiş, GSYİH'dan enerji tüketimine doğru nedenselliğin gerçekleştiği ve söz konusu değişkenlerin uzun dönemde birlikte hareket ettikleri sonucuna varılmıştır.

Masih ve Masih (1997), Güney Kore ve Tayvan için enerji tüketimi, enerji fiyatları ve gelir arasındaki ilişkiyi incelemiş ve değişkenler arasında karşılıklı nedensellik ilişkisi olduğu sonucuna ulaşmışlardır. 
Efeoğlu R., Pehlivan C.. (2018), “Türkiye'de Enerji Tüketimi ve Cari Açı̆̆ın Ekonomik Büyüme Üzerine Etkileri” Politik Ekonomik Kuram, Cilt 2(1)

Mucuk ve Uysal (2009) yaptığı çalışma, eşbütünleşme ve Granger Nedensellik testleri kullanarak Türkiye için enerji tüketimi ile ekonomik büyüme arasındaki ilişkiyi incelemektedir. Değişkenlerin eşbütünleşik olup enerji tüketiminden ekonomik büyümeye doğru nedenselliğin olduğu sonucuna varılmıştır.

Nasreen ve Anwar (2014,) Asya ekonomileri üzerine yaptıkları çalışmada ekonomik büyüme, ticari açıklık ve enerji tüketimi ilişkisini incelemiştir. Ekonomik büyüme ve ticari açıklığın enerji tüketimi üzerinde pozitif etkileri olduğunu, enerji tüketimi ve ticari açıklık değişkenleri arasında ise çift yönlü nedensellik ilişkisinin bulunduğunu ortaya koymuştur.

Odhiambo (2009), Tanzanya'da 1971- 2006 dönemi için ekonomik büyüme ve enerji tüketimi arasındaki ilişkiyi analiz etmiştir. Sınır testi ve Granger Nedensellik testleri sonucunda uzun dönemli değişkenlerin birlikte hareket ettiklerini ve enerji tüketiminden ekonomik büyümeye doğru tek yönlü bir ilişkinin ortaya çıktığını göstermiştir.

Özçağ (2015)'ın yaptığı çalışmada, Türkiye'de nihai enerji tüketimi, GSYİH ve dışa açıklık değişkenleri arasındaki ilişki ARDL Modeli ve Hata Düzeltme Modeli çerçevesinde incelenerek nihai enerji tüketimi ve dışa açıklık arasında istatistiki olarak anlamlı sonuç yok iken, nihai enerji tüketimi ve GSYİH artışı arasında anlamlı bir sonuç olduğu görülmüştür.

Paul vd. (2004) yaptıkları çalışmada, Hindistan’da 1950-1996 yılları arasında enerji tüketimi ve ekonomik büyüme arasında nedensellik ilişkisinin yönünü araştırmışlardır. Enerji tüketimi ile ekonomik büyüme arasında iki yönlü bir nedenselliğin olduğu sonucunu elde etmişlerdir.

Sadorsky (2012), Güney Amerika ülkelerinde enerji tüketimi ile ihracat ilişkisini analiz etmiş, değişkenler arasında kısa dönemde tek yönlü bir ilişki, uzun dönemde ise karşılıklı bir nedensellik ilişkisinin bulunduğu sonucuna varılmıştır.

Sarı, Soytaş ve Özdemir (2001), Türkiye için 1960-1995 döneminde enerji tüketimi ile GSYİH arasındaki ilişkiyi analiz etmişlerdir. Çalışma sonucunda Johansen Eşbütünleşme testinde enerji tüketimi ile GSYİH arasında uzun dönemli ilişki olduğu, nedensellik ilişkisinin ise elektrik tüketiminden gelire doğru tek yönlü olduğu sonucu ortaya çıkmıştır.

Sbia, Shahbaz ve Hamdi (2014) yaptığı çalışmada, Birleşik Arap Emirliklerinde 19752011 dönemi için doğrudan yabancı yatırım, temiz enerji, ticaret açıklığı, karbon emisyonları ve ekonomik büyüme arasındaki ilişkiyi incelemişlerdir. Seriler arasında eşbütünleşme olduğunu; doğrudan yabancı yatırım, ticari açıklık ve karbon emisyonlarının enerji talebini azalttığını, ekonomik büyüme ve temiz enerjinin enerji tüketimi üzerinde olumlu etkisi olduğunu elde etmiştir. 
Efeoğlu R., Pehlivan C.. (2018), “Türkiye'de Enerji Tüketimi ve Cari Açı̆̆ın Ekonomik Büyüme Üzerine Etkileri” Politik Ekonomik Kuram, Cilt 2(1)

Shahbaz vd. (2014), 1980-2010 döneminde 91 yüksek, orta ve düşük gelirli ülkelerin enerji tüketimi ve ticari açıklık ilişkisini araştırmıştır. Çalışma sonucunda ticari açıklık ve enerji tüketimi değişkenleri arasında eşbütünleşme olduğunu, ayrıca her iki değişken arasında tek yönlü bir nedensellik ilişkisi olduğu sonucuna varmışlardır.

Tsani (2010), Yunanistan'da 1960-2006 dönemi için Granger Nedensellik ve VAR analizini kullanarak ekonomik büyüme ve enerji tüketimi arasındaki ilişkiyi analiz etmiştir. Çalışma sonucunda toplam enerji tüketiminden reel GSYİH'ya doğru nedenselliğin gerçekleştiğini ortaya koymuştur.

Yalta (2011) yaptığı çalışmada, Türkiye'de 1950-2006 döneminde enerji tüketimi ve GSYİH ilişkisini incelemiş ve enerji tüketimi ve GSYİH arasında nötr bir ilişki olduğu sonucuna varmıştır.

Yanar ve Kerimoğlu (2011) tarafından yapılan çalışmada, 1975-2009 yılları arasında Türkiye'de enerji tüketimi, ekonomik büyüme ve cari açık ilişkisini eşbütünleşme testi doğrultusunda analiz edilmiştir. Johansen Eşbütünleşme analizi testi yapılarak enerji tüketimi, ekonomik büyüme ve cari açık arasında uzun dönemli bir ilişki olduğu, Vektör Hata Düzeltme Modeli ile de büyüme arttıkça enerji tüketiminde de artış meydana geleceğini, enerji tüketimindeki artış ise cari açığı arttırıcı etki yapacağı sonucuna varılmıştır.

Yapraklı ve Yurttançıkmaz (2012), Türkiye'de 1970-2010 dönemi için elektrik tüketimi ile ekonomik büyüme arasındaki ilişkiyi eşbütünleşme ve hata düzeltme geliştirilmiş Granger Nedensellik testleri ile incelemiştir. Türkiye'de elektrik tüketimi ile ekonomik büyüme arasında çift yönlü bir nedenselliğin olduğu görülmüştür.

\section{Metodoloji, Veri ve Uygulama}

Enerji tüketimi ve ekonomik büyüme ilişkisi çok fazla sayıda çalışmaya konu olmasına rağmen Türkiye ekonomisi üzerinde söz konusu ilişkiler incelemeye alınırken mevcut iki değişkene ek olarak cari açık değişkeni de analize dahil edilmiştir. Kullanılan değişkenler 1987-2016 dönemini kapsamaktadır. Enerji tüketimi, ekonomik büyüme ve cari açık ilişkisinde; enerji tüketimi verisi ETKB'den bin tep olarak tanımlanmıştır. Ekonomik büyüme için GSYİH 
Efeoğlu R., Pehlivan C.. (2018), “Türkiye'de Enerji Tüketimi ve Cari Açı̆̆ın Ekonomik Büyüme Üzerine Etkileri” Politik Ekonomik Kuram, Cilt 2(1)

değerlerine bakılmaktadır. GSYİH verisi, Dünya Bankasından cari fiyatlarla milyon \$ olarak yararlanılmıştır. Cari açık verisi ise, TCMB'den milyon \$ olarak tanımlanmıştır.

Çalışmada zaman serisi yöntemi kullanılarak verilerin ekonometrik analizi için E-views programı kullanılmıştır. Analize konulan enerji tüketimi ve GSYİH değişkenlerinin logaritması alınarak analize dahil edilmiştir. Cari açık değişkeni ise doğal değerleri alınarak kullanılmıştır. İlk olarak değişkenlerin durağanlıkları Augmented Dickey-Fuller (ADF) ve Phillips-Perron (PP) testi ile sınanmış daha sonra sırasıyla VAR analizi yapılarak gecikme uzunlukları; değişkenler arasında uzun dönemli ilişkinin olup olmadığına ilişkin Johansen eşbütünleşme testi; hata düzeltme modeli, etki tepki analizi, varyans ayrıştırma, Granger nedensellik ve Toda Yamamato nedensellik analizi testleri yapılarak çalışmanın sonunda araştırma bulgularından hareketle sonuç sunulmuştur.

Zaman serisinde Augmented Dickey Fuller ve Phillips- Perron testi değişkenlerin birim köke sahip olup olmadığını incelemeye ve analiz etmeye çalışan bir testtir. Granger ve Newbold 1974 yılında yaptıkları çalışmada değişkenlerin durağan olmaması durumunda seride sahte regresyon problemi olabileceğini saptamışlardır (Sevüktekin ve Nargeleçekenler, 2007). Augmented Dickey Fuller testi hata terimlerinin sabit varyans içerdiklerini kabul eder. Değişkenlere gecikmeli değerler eklenmiş ve ADF birim kök testi otokorelasyon sorunundan arındırılmıştır. Phillips Perron birim kök testi seride hata teriminin homojen bir yapı sergilemesine izin vermemektedir. Böylelikle seride otokorelasyon sorunu yaşanmamaktadır (Enders, 2004).

Phillips Perron testinde, Dickey Fuller birim kök testinde hata terimleri için kullanılan önermeler daha geniş bir varsayımla açıklanmıştır. Phillips Perron testi hata terimleriyle ilgili sınırlayıcı varsayımlar kullanılmaz. Ayrıca bu testte otokorelasyonu gidermek için gerekli değişkenlerin gecikmeli değerleri modele dahil edilmemektedir. Gecikmeli değerin belirlenmesi için Newey-West tahmin değeri kullanılmaktadır. Kritik değerin test istatistik değerinden küçük olması seride değişkenlerin durağan olduğunu göstermektedir (Altunç, 2008).

Birim kök içeren değişkenler ampirik sonuçları saptırabildiğinden ve sahte sonuçlara yol açabildiğinden, zaman serilerinde birim kök testinin uygulanması oldukça önemli bir konudur (Özçă̆, 2015). Tablo 1'de ADF ve PP birim kök testi sonuçları verilmiştir. 
Tablo 1: Birim Kök Testleri Sonuçları

$\mathbf{I}(\mathbf{0})$

I(1)

\begin{tabular}{cccccc}
\hline Seriler & ADF & Olasılık & Değişkenler & ADF & Olasılık \\
\hline GSYİH & -1.953381 & 0.9591 & GSYİH & -1.953859 & $0.0001^{* * *}$ \\
Cari Açık & -1.953381 & 0.2626 & Cari Açık & -1.953858 & $0.0000^{* * *}$ \\
Enerji & -1.953381 & 0.9994 & Enerji & -1.953858 & $0.0003^{* * *}$ \\
\hline \multicolumn{7}{c}{ Phillips-Perron (PP) Birim Kök Test Sonuçları } \\
\hline GSYíH & -1.953381 & 0.9450 & GSYİH & -1.953858 & $0.0002^{* * *}$ \\
Cari Açık & -1.953381 & 0.3429 & Cari Açık & -1.953858 & $0.0000^{* * *}$ \\
Enerji & -1.953381 & 1.0000 & Enerji & -1.953858 & $0.0004^{* * *}$ \\
\hline
\end{tabular}

Not: ***\%1 anlamlılık düzeyini göstermektedir.

Analizde değişkenler için ADF ve PP birim kök testleri uygulanmıştır. Seriye ait değişkenlerin düzey değerinde yani $\mathrm{I}(0)$ 'da durağan olmadıkları saptanmıştır. Değişkenlerin durağanlığın sağlanması için birinci farkları alınmıştır. Seride birim kökün olmadığını varsayan $\mathrm{H}_{1}$ hipotezi kabul edilirken, birim kökün olduğunu varsayan Ho hipotezi reddedilmiştir. Cari açık, enerji tüketimi ve GSYİH arasındaki ilişkinin belirlenmesi için uygun gecikme uzunluğu bulunmuştur.

Tablo 2: VAR Modeli Gecikme Uzunluğu

\begin{tabular}{|c|c|c|c|c|c|c|}
\hline Lag & LogL & LR & FPE & AIC & SC & HQ \\
\hline 0 & -888.2105 & NA & $1.19 \mathrm{e}+26$ & 68.55466 & 68.69982 & 68.59646 \\
\hline 1 & -833.7554 & $\mathbf{9 2 . 1 5 4 9 2} *$ & $\mathbf{3 . 6 3 e + 2 4} *$ & $\mathbf{6 5 . 6 3 8 7 6}^{*}$ & $\mathbf{6 3 . 1 4 5 9 2}^{*}$ & $\mathbf{6 5 . 2 2 5 3 1} *$ \\
\hline 2 & -829.9838 & 5.512340 & $5.61 \mathrm{e}+24$ & 65.46029 & 66.47644 & 65.75290 \\
\hline
\end{tabular}

Tablo 1'de görüldüğü üzere, düzey değerde GSYİH, cari açık, enerji tüketimi değişkenleri, birim kök içermektedir. Dolayısıyla Ho hipotezi kabul edilmiştir. Kısa dönemli analiz yapılamayacağı, ancak uzun dönemli analiz yapılabileceği anlaşılmıştır. ADF birim kök testi sonrasında analizin gecikme uzunlukları SC ve HQ kriterleri ile belirlenmiştir. VAR modeli analizi kriterlerin tamamına göre optimal gecikme uzunluklarının Tablo 2'de görülebileceği üzere 1 olduğuna karar kılınmıştır. VAR analizi gecikme ölçümü sonucunda görüldügü üzere Türkiye ekonomisinde GSYİH, cari açık, enerji tüketimi değişkenlerinin bir dönem önceki değerleri ile bir ilişkisinin bulunduğu sonucuna varılmıştır. Seçilen gecikme uzunluğu Johansen 
Efeoğlu R., Pehlivan C.. (2018), “Türkiye'de Enerji Tüketimi ve Cari Açı̆̆ın Ekonomik Büyüme Üzerine Etkileri” Politik Ekonomik Kuram, Cilt 2(1)

Eşbütünleşme testinde kullanılmıştır. Serilerin I(1) farklarıyla aynı derecede durağanlık göstermeleriyle, sahte nedensellik ilişkisini engelleyebilmek adına Johansen Eşbütünleşme testi yapılmıştır. Bu test sayesinde söz konusu değişkenler arasında uzun dönemli bir ilişkinin bulunup bulunmadığ 1 tespit edilmiştir.

Tablo 3: Johansen Eşbütünleşme Testi

\begin{tabular}{|c|c|c|c|}
\hline İz testi & \%5 kritik değer & Olasılık değeri & Eşbütünleşme sayısı \\
\hline 36.668 & 35.192 & 0.0344 & Hiç yok \\
\hline 17.628 & 20.261 & 0.110 & En çok bir tane \\
\hline 5.238 & 9.164 & 0.258 & En çok iki tane \\
\hline
\end{tabular}

Eşbütünleşme analizde iz testinin kritik değerden büyük olması ve olasılık değerinin eşik değerlerde $(\% 1,5, \% 10)$ olması durumunda değişkenler arasında eşbütünleşmenin varlığını kabul eden Hı hipotezi kabul edilir ve katsayıların anlamlı olduğu sonucuna varılır (Tarı, 2012: 435). Tablo 3'e göre Analiz sonucunda iz testi değeri 36.668, kritik değer olan 35.191'den büyüktür. Eşbütünleşmenin olması değişkenler arasında uzun dönemli bir ilişkinin olduğunu göstermektedir.

Yaptığımız analizlerde değişkenler arasında eşbütünleşme olduğu tespit edildikten sonra Hata Düzeltme Modeli (Vector Error Correction Model, VECM) tahmin edilmiştir. Değişkenler arasında uzun dönem denge varsayımı vardır. Ancak kısa dönemde bu uzun dönem dengesinden sapmalar oluşmaktadır. Ayrıca serilerin farkları alınarak durağan hale getirilmesi sonucu, serilerin verilerinde değer kayıpları oluşmuştur. Bu değer kayıpları da sonuçlar üzerinde olumsuz etki bırakabileceği uzun dönemde bu sapmaların ne kadarlık sürede yok olacağını belirlemek için Hata Düzeltme Modeli uygulanmıştır.

Tablo 4: Hata Düzeltme Modeli

\begin{tabular}{|c|c|c|c|}
\hline Hata Düzeltme & D (GSYİH) & D(CARİ AÇIK) & D(ENERJi) \\
\hline Hata Düzeltme Katsayısı & $\mathbf{- 0 . 0 5 2 8 7 9}$ & -3.354527 & 0.015759 \\
\hline Standart hata & 0.148480 & 0.546444 & 2.066883 \\
\hline t Hesaplanan Değeri & {$[-3.561364]$} & {$[-6.138831]$} & {$[-0.007625]$} \\
\hline
\end{tabular}

Görüldüğü üzere, hata düzeltme modeli sonuçları yer almaktadır. Söz konusu verilerle kısa dönem içerisindeki uzun dönemden sapmalar kaç dönem içerisinde yeniden dengeye geleceğini 1/ECM formülü sayesinde gerçekleştirilecektir. Katsayı değerinin anlamlı 
Efeoğlu R., Pehlivan C.. (2018), “Türkiye'de Enerji Tüketimi ve Cari Açı̆̆ın Ekonomik Büyüme Üzerine Etkileri” Politik Ekonomik Kuram, Cilt 2(1)

olabilmesi için 0 ile - 1 aralığında bir değer almalıdır. Aynı zamanda t Hesaplanan Değerinin de 2'nin üzerinde bir değer alması gerekmektedir (Tar1, 2012: 435). ECM değeri 1'e ne kadar yakınsa uzun dönem dengesi o kadar kısa zamanda yakalanır. Tablo 4'de hata sonuçlarına göre düzeltme katsayıs1 -0.052 bulunmuştur. Hata düzeltme parametresi istatistiksel olarak anlamlıdır ve negatiftir (- 0.052). Hata düzeltme katsayısı GSYİH gözlenen değeriyle uzun dönem değeri arasındaki farkın her yıl yaklaşık olarak yüzde 5'inin [ ECT(-1) = -0.052) ] ortadan kalktığı ve düzelmenin olup uzun dönem denge değerine varılabileceğini göstermektedir.

Kısa dönem modeli ise;

$$
\Delta G S Y \dot{I} H_{t}=\beta_{0}+\sum_{i=1}^{p} \beta_{1 i} \Delta \text { Enerji Tüketimi } t_{t-i}+\sum_{i=1}^{q} \propto_{2 i} \Delta \text { Cari Açl } k_{t-i}+\sum_{i=1}^{r} \alpha_{3 i} \Delta G S Y \dot{I} H_{t-i}+\psi_{1}+\mu_{2 t}
$$

şeklinde ifade edilir.

VAR analizi değişkenler arasındaki ilişkiyi açıklamak ve değişkenlerin birbiri üzerindeki etkisini incelemek için kullanılmaktadır. Seride kullanılan değişkenlerin ekonomik analizlerinde yaşanan şokların etkilerini incelemek için etki tepki testi yapılmaktadır. Şekil l'de GSYİH'nın, bağımsız değişken olan cari açık ve enerji tüketimi için on dönemlik periyotta meydana gelen şoklara verdiği tepki gösterilmiştir.

Response to Cholesky One S.D. Innovations \pm 2 S.E.Response to Cholesky One S.D. Innovations \pm 2 S.E.
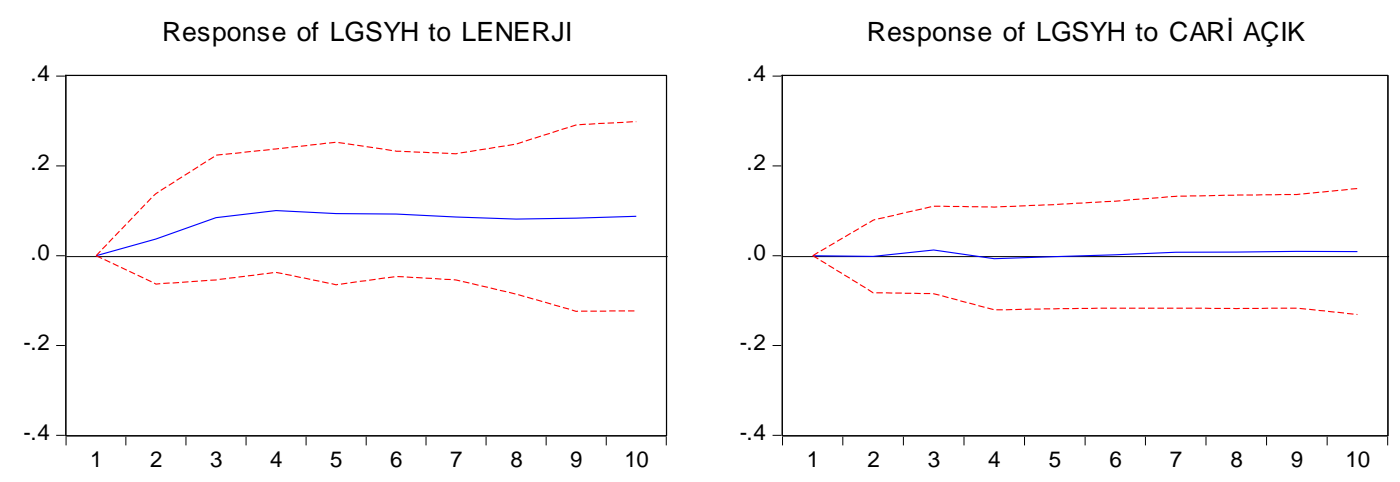

Response to Cholesky One S.D. Innovations \pm 2 S.E.

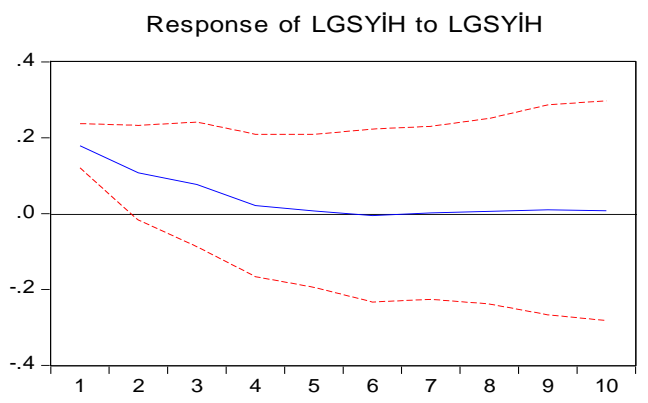

Grafik 2: Bir Standart Hatalık Şoka GSYİH'nın Verdiği Tepki 
Efeoğlu R., Pehlivan C.. (2018), “Türkiye'de Enerji Tüketimi ve Cari Açı̆̆ın Ekonomik Büyüme Üzerine Etkileri” Politik Ekonomik Kuram, Cilt 2(1)

Grafik 2'ye göre GSYİH'nın enerji değişkenine gösterdiği tepki izlenen on dönem için iktisadi açıdan anlamlı ve pozitiftir. Ancak GSYİH’nın cari açıkta meydana gelen şoklara gösterdiği tepki teoriye uygun bir sonuç yansıtmamaktadır. Çıkan sonuç istatistiksel açıdan anlamsızdır. GSYİH'nın kendisinden gelen şoklara tepkisi ise; ilk dört dönem için pozitif iken, dördüncü dönemden sonra şokun etkisi sönmektedir.

Değişkenler arasında meydana gelecek bir değişmenin birbirleri üzerindeki etkisini ölçmek için varyans ayrıştırılması analizi yapılmaktadır. Bu analiz seride kullanılan her bir değişkenin öngörü hatasının varyansını tüm içsel değişkenlere göre ayrıştırıp incelemektedir. Herhangi bir değişkende oluşacak bir birimlik değişmenin yüzde kaçının kendinden, yüzde kaçının başka bir değişkenden dolayı oluşacağını test etmek için kullanılmaktadır (Enders,1995).

Tablo 5: Var Sisteminde Kullanılan Değişkenlerin Varyans Ayrıştırması (GSYİH İçin)

\begin{tabular}{|l|c|c|c|c|}
\hline \multicolumn{5}{|c|}{ Şoklar } \\
\hline Değişkenler & Dönemler & GSYİH & \multicolumn{1}{l|}{$\begin{array}{l}\text { Enerji } \\
\text { Tüketimi }\end{array}$} & Cari Açık \\
\hline & 1 & 100.000 & 0.000 & 0.000 \\
LGSYİH & 2 & 96.904 & 3.087 & 0.007 \\
& 3 & 85.061 & 14.666 & 0.271 \\
& 4 & 72.677 & 27.025 & 0.297 \\
& 5 & 64.433 & 35.295 & 0.271 \\
& 6 & 57.993 & 41.758 & 0.248 \\
& 7 & 53.356 & 46.355 & 0.288 \\
& 8 & 49.825 & 49.839 & 0.334 \\
& 9 & 46.592 & 53.009 & 0.398 \\
& 10 & 43.493 & 56.065 & 0.441 \\
\hline
\end{tabular}

Tablo 5' te analizde kullanılan tüm değişkenler için on dönemlik varyans ayrıştırma sonuçları verilmektedir. GSYİH'da meydana gelecek olan bir birimlik değişme ilk dönemde sadece kendinden kaynaklanmaktadır. İzleyen dönemlerde enerji tüketimi ve cari açık üzerindeki etkisi hissedilmektedir. On gecikmeli dönemde GSYİH'nın varyansı \% 43 oranında kendisinden, \% 56 ' s1 enerji tüketiminden, \% 0.44 'ü ise cari açıktan meydana gelen şoklardan kaynaklanmaktadır.

Tablo 6: Granger Nedensellik Testi

\begin{tabular}{|c|c|c|c|}
\hline $\begin{array}{c}\text { Ho (granger nedeni } \\
\text { değildir) }\end{array}$ & F istatistik & Olasılık & Karar \\
\hline
\end{tabular}


Efeoğlu R., Pehlivan C.. (2018), “Türkiye’de Enerji Tüketimi ve Cari Açı̆̆ın Ekonomik Büyüme Üzerine Etkileri” Politik Ekonomik Kuram, Cilt 2(1)

\begin{tabular}{|c|c|c|c|}
\hline GSYİH $=/ /=>$ CARİ AÇIK & 2.8961 & $0.0755^{*}$ & Ho RED \\
\hline ENERJ்̇ $=/ /=>$ GSYİH & 2.8961 & $0.0761^{*}$ & Ho RED \\
\hline ENERJİ $=/ /=>$ CARİ AÇIK & 2.0252 & $0.0452^{* *}$ & Ho RED \\
\hline
\end{tabular}

Not: ${ }^{* * *}, * * *$ sirasıyla $\% 10, \% 5, \% 1$ anlamlılık düzeyini göstermektedir.

Serilerin eşit dereceden durağan olması sonucu, seriler arasında eşbütünleşme aranmakta ve eşbütünleşmenin izlenmesi durumunda da, seriler arasında nedensellik ilişkisi aranabilmektedir. Bu bağlamda Granger Nedensellik testi için; Ho : "Hiçbir Granger nedeni yok" şeklinde ifade edilirse analizde kullanılan değişkenler arasında bir ilişkinin olmadığg kabul edilir (Tarı, 2012: 400-460). Görüldüğü üzere tablo 6'ya göre; GSYİH'dan cari açığa, enerji tüketiminden de GSYİH ve cari açığa doğru tek yönlü bir nedensellik ilişkisi bulgusuna ulaşılmıştır. Başka bir ifadeyle GSYİH, cari açığın Granger nedenidir ve GSYİH, cari açığı etkilemektedir. Aynı şekilde enerji tüketimi de hem GSYİH hem de cari açığın Granger nedenidir; enerji tüketimi GSYİH ve cari açı̆̆ı etkilemektedir.

1995 yılında oluşturulan Toda-Yamamoto nedensellik analizi için Wald testi uygulanmaktadır. Değişkenlerin düzey değerlerinde VAR modeli oluşturulur. Böylece serilerin eş bütünleşme derecelerini belirlerken oluşan sorunlar yok edilir. Wald testinin dağılımı VAR modelinde bulunan gecikme sayısı (k) ve serilerin durağanlık derecesine (dmax) göre belirlenmektedir. İki değerin belirlenmesiyle $(\mathrm{k}+\mathrm{dmax})$ seviyesinde Toda-Yamamoto nedensellik testi uygulanır (Zapata 1997, Duasa, 2007). Denklemsel olarak;

$\operatorname{In} X_{t}=\sum_{i=1}^{k+d} \beta_{1 i} \operatorname{In} X_{t i}+\sum_{i=1}^{k+d} \alpha_{1 i} \operatorname{In} Y_{t i}+\mu_{1 t}$

$\operatorname{In} Y_{t}=\sum_{i=1}^{k+d} \beta_{2 i} \operatorname{In} Y_{t i}+\sum_{i=1}^{k+d} \alpha_{2 i} \operatorname{In} X_{t i}+\mu_{2 t}$

şeklinde ifade edilir. (Taşar, 2015: 58)

Denklemde yer alan $\mathrm{i} \leq \mathrm{k}$ koşulu için sıfır hipotezi $\alpha_{1 i}=0$ olarak kabul edilir. Buna karşın alternatif hipotezin kabul edilmesi durumunda $Y t^{\prime}$ den, $\mathrm{Xt}^{6}$ ye doğru nedensellik ilişkisinin olmadığg öngörülür. Ancak sıfır hipotezi i $\leq \mathrm{k}$ koşulu için $\alpha_{2 i}=0$ olarak test edilirse alternatif hipotez kabul edilir ve Xt'den, Yt‘'ye doğru nedensellik ilişkisinin olduğu saptanır.

Tablo 7: Toda- Yamamato Nedensellik Testi 


\begin{tabular}{|l|c|c|c|}
\hline Hipotezler & $\begin{array}{c}\text { Optimal Gecikme } \\
\text { Uzunluğu } \\
\left(\mathrm{k}+\mathrm{d}_{\max }\right)\end{array}$ & Wald $(\chi 2)$ & Olasılık \\
\hline Cari Açık $\neq$ GSYİH & 2 & 4,158 & $0,067^{*}$ \\
\hline GSYİH $\neq>$ Cari Açık & 2 & 4,789 & 0,884 \\
\hline Enerji Tüketimi $\neq>$ GSYİH & 2 & 3,185 & $0,002^{* * *}$ \\
\hline GSYİH $\neq>$ Enerji Tüketimi & 2 & 1,758 & 0,280 \\
\hline
\end{tabular}

Not: ${ }^{* * *},{ }^{* * *}$ sirasıyla $\% 10, \% 5, \% 1$ anlamlılık düzeyini göstermektedir.

Tablo 7'de yer alan Toda- Yamamato Nedensellik analizi sonucunda; cari açıktan GSYİH'ya doğru \%10 seviyesinde nedenselliğin ve enerji tüketiminden GSYİH’ya doğru \%1 anlam seviyesinde bir nedenselliğin olduğu görülmektedir. Çıkan sonuçlar Granger Nedensellik testiyle benzerlik göstermektedir.

\section{Sonuç}

Bu çalışmanın amacı, Türkiye'nin 1987-2016 yılları arasındaki enerji tüketimi, ekonomik büyüme ve cari açık ilişkisini analiz etmektir. Literatürde enerji tüketimi ve ekonomik büyüme ilişkisine dair birçok çalışma yapılmış ancak enerji tüketimi, ekonomik büyüme ve cari açık ilişkisini analiz eden çalışmaya pek rastlanılmamıştır. Dolayısıyla cari açık değişkeni, enerji tüketimi ve ekonomik büyüme değişkenlerine eklenerek analize dahil edilmiş ve sonuçlar görülmüştür.

Bu çalışma daha önce yapılan çalışmalar içerisinde Demirbaş vd. (2009), Kar ve Kınık (2008), Mucuk ve Uysal (2009), Özçağ (2015), Apergis ve Payne (2010), Hondroyiannis vd. (2002), Odhiambo (2009), Glasure ve Lee (1997), Soytaş ve sarı (2003), Tsani (2010), Lee (2005)'nin yapmış oldukları çalışmalar ile aynı sonuca ulaşırken literatür içerisinde bulunan diğer çalışmaları desteklememektedir. Çalışmada uygulanan analiz doğrultusunda enerji tüketimi, ekonomik büyüme ve cari açık değişkenleri arasında düzey değerlerinde durağanlık bulunmadığı için, ADF ve PP testi ile değişkenlerin birinci farkları alınarak değişkenler arasında durağanlık sağlanmıştır. Johansen Eşbütünleşme testi doğrultusunda değişkenler arasında uzun dönemli ilişkinin olup olmadığına bakılmış ve değişkenler arasında uzun dönemli ilişki olduğu tespit edilmiştir. Analizde katsayıların anlamlı çıkması sonucunda hata düzeltme 
Efeoğlu R., Pehlivan C.. (2018), “Türkiye'de Enerji Tüketimi ve Cari Açı̆̆ın Ekonomik Büyüme Üzerine Etkileri” Politik Ekonomik Kuram, Cilt 2(1)

modeli gerçekleştirilmiştir. Hata Düzeltme katsayısı negatif ve anlamlı bulunmuştur. Ekonomik analizlerde yaşanan şokların etkilerini incelemek için yapılan etki tepki testi analizi ile GSYİH’nın enerji tüketiminde meydana gelen artıştan etkilendiği, enerji tüketimi arttıkça ekonomik büyümede de artış meydana geleceği görülmüştür. Ancak tam tersine GSYİH'nın cari açıkta meydana gelen artışlardan etkilenmediği, cari açık arttıkça ekonomik büyümede artış ortaya çıkmadığı gözlemlenmiştir. Bunun yanı sıra varyans ayrıştırması testi sonucunda GSYİH'nın varyansı ilk dönemde sadece kendinden, izleyen dönemlerde ise enerji tüketimi ve cari açıktan kaynaklanmaktadır. Ayrıca analizde gerçekleştirilen Granger Nedensellik ve TodaYamamato Nedensellik testleri sonucunda GSYİH ile cari açık, enerji tüketimi ile GSYİH ve cari açık arasında tek yönlü bir nedensellik meydana gelmektedir. GSYİH artışı cari açığı artırmakta, enerji tüketimi artışı da hem büyümeyi hem de cari açığı artırmaktadır.

\section{Kaynakça}

Akinlo, A.E., 2008. Energy consumption and economic growth: Evidence from 11 Sub-Sahara African countries. Energy Economics, 30, 2391-2400.

Altınay, G. ve Karagöl E., 2004. Structural Break, Unit Root, And The Causality Between Energy Consumption and GDP İn Turkey. Energy Economics, 26, 985-994.

Altunç, Ö. F., 2008. Türkiye'de Finansal Gelişme ve İktisadi Büyüme Arasındaki Nedenselliğin Ampirik Bir Analizi. Eskişehir Osmangazi Üniversitesi İIBF Dergisi, 3(2), 113-127.

Apergis, N. ve Payne J.E., 2010. Energy consumption and growth in South America: Evidence from a panel error correction model. Energy Economics, 32, 1421-1426.

Chen, S.T., Kuo, H. ve Chen C.C., 2007. The relationship between GDP and electricity consumption in 10 Asian countries. Energy Policy, 35, 2611-2621.

Cheng, B.S., 1997. Energy consumption and economic growth in Brazil, Mexico and Venezuela: a time series analysis. Applied Economics Letters, 4(11), 671-674.

Chontanawat, J., HuntL, C. ve Pierse, R., 2006. Causality between Energy Consumption and GDP: Evidence from 30 OECD and 78 Non-OECD Countries. Surrey Energy Economics Centre (SEEC) Department of Economics, 113, 1-58.

Demirbaş, M., Türkay, H. ve Türkoğlu, M., 2009. Petrol Fiyatlarındaki Değişmelerin Türkiye'nin Cari Açı̆̆ı Üzerine Etkisinin Analizi. Süleyman Demirel Üniversitesi I.I..B.F Dergisi, 14(3), 289-299.

Dünya Bankası (http://www.worldbank.org/tr/country/turkey), Erişim tarihi: 20.03.2018

Dünya Enerji Konseyi Türk Milli Komitesi 2014 Raporu. Ankara 
Efeoğlu R., Pehlivan C.. (2018), “Türkiye'de Enerji Tüketimi ve Cari Açı̆̆ın Ekonomik Büyüme Üzerine Etkileri” Politik Ekonomik Kuram, Cilt 2(1)

Ebohon, O. J., 1996. Energy, economic growth and causality in developing countries. Energy Policy, 24(5), 447-453.

Enders, W. 2004. Applied Econometrics Time Series, Newyork: John Wiley and Sons.

Enerji ve Tabii Kaynaklar Bakanlığı (http://www.enerji.gov.tr), Erişim tarihi: 20.03.2018

Esmer, O., 1996. Enerji Politikaları. TMMOB Türkiye Enerji Sempozyumu. 12- 24 Kasım 1996 Ankara. TMMOB Yayınları, 223-234.

Glasure, Y.U. ve Lee A. R., 1997. Cointegration, error-correction, and the relationship between GDP and energy: The case of South Korea and Singapore. Resource and Energy Economics, 20, 17-25.

Güvenek, B. ve Alptekin, V., 2010. Enerji Tüketimi ve Büyüme İlişkisi: OECD Ülkelerine İlişkin Bir Panel Veri Analizi. Enerji, Piyasa ve Düzenleme, 2(1), 172-193.

Heinrich Böll Stiftung Derneği, 2008. Enerji Verimliliği Teknik Kitapçı̆̆ı, İstanbul, Birinci Bask1.

Hondroyiannis, G., ve Lolos, S. ve Papapetrou, E., 2002. Energy consumption and economic growth: assessing the evidence from Greece. Energy Economics, 24, 319-336.

Hossain, M.S., 2011. Panel estimation for CO2 emissions, energy consumption, economic growth, trade openness and urbanization of newly industrialized countries. Energy Policy, 39, 6991-6999.

International Energy Agency, Key World Energy Statistics, 2016. Ankara.

Jobert, T. ve Karanfil, F., 2007. Sectoral energy consumption by source and economic growth in Turkey. Energy Policy, 35, 5447-5456.

Kar, M.ve Kınık, E., 2008. Türkiye'de Elektrik Tüketimi Çeşitleri ve Ekonomik Büyüme Ekonometrik Bir Analizi. Afyon Kocatepe Üniversitesi İ.̇.B.F Dergisi, 10(2), 333-353.

Karagöl, E., Erbaykal, E. ve Ertuğrul, H.M., 2007. Türkiye'de Ekonomik Büyüme İle Elektrik Tüketimi İlişkisi: Sınır Testi Yaklaşımı. Doğuş Üniversitesi Dergisi, 8 (1), 72-80.

Lee, C.C., 2005. Energy consumption and GDP in developing countries: A cointegrated panel analysis. Energy Economics, 27, 415-427.

Lise, W. ve Van Montfort, K., 2005. Energy Consumption And GDP In Turkey: Is There A Cointegration Relationship?. ECN Policy Studies, 8(3), 1-12.

Masih, A.M.M. ve Masih, R., 1997. On the Temporal Causal Relationship Between Energy Consumption, Real Income, and Prices: Some New Evidence From Asian-Energy Dependent NICs Based on A Multivariate CointegrationNector Error-Correction Approach. Journal of Policy Modeling, 19(4), 417-440. 
Efeoğlu R., Pehlivan C.. (2018), “Türkiye'de Enerji Tüketimi ve Cari Açı̆̆ın Ekonomik Büyüme Üzerine Etkileri” Politik Ekonomik Kuram, Cilt 2(1)

Mucuk, M. ve Uysal, D., 2009. Türkiye Ekonomisinde Enerji Tüketimi ve Ekonomik Büyüme. Maliye Dergisi, 157, 105-115.

Nasreen, S. ve Anwar. S., 2014. Causal relationship between trade openness, economic growth and energy consumption: A panel data analysis of Asian countries. Energy Policy, 69, 82-91.

Odhiambo, N.M., 2009. Energy consumption and economic growth nexus in Tanzania: An ARDL bounds testing approach. Energy Policy, 37, 617-622.

Özçağ, M., 2015. Türkiye'de Enerji Tüketimi, Ekonomik Büyüme ve Dışa Açıklık İlişkisi: ARDL Modeli. Finansal Politik\&Ekonomik Yorumlar, 605(52), 7-17.

Paul, S. ve Bhattacharya, R.N., 2004. Causality between energy consumption and economic growth in India: a note on conflicting results. Energy Economics, 26, 977-983.

Sadorsky, P., 2012. Energy consumption, output and trade in South America. Energy Economics, 34, 476-488.

Sbia, R., Shahbaz, M. ve Hamdi, H., 2014. A contribution of foreign direct investment, clean energy, trade openness, carbon emissions and economic growth to energy demand in UAE. Economic Modelling, 36, 191-197.

Sevüktekin, M. ve Nargeleçekenler, M. 2007. Ekonometrik Zaman Serileri Analizi. Ankara: Nobel Yayın Dağıtım Ltd.

Shahbaz, M., Nasreen, S., Ling, C.H. ve Sbia, R. 2014. Causality between trade openness and energy consumption: What causes what in high, middle and low income countries. Energy Policy, 70, 126-143.

Soytaş, U. ve Sari, R., 2003. Energy consumption and GDP: causality relationship in G-7 countries and emerging markets. Energy Economics, 25, 33-37.

Taşar, İ., 2015. İçsel Büyüme Modelleri Çerçevesinde Türkiye' de Ekonomik Büyümenin Yapısal Dönüşümü. Yayımlanmamış Doktora Tezi. İnönü Üniversitesi.

Tsani, S.Z., 2010. Energy consumption and economic growth: A causality analysis for Greece. Energy Economics, 32, 582-590.

Türkiye Cumhuriyet Merkez Bankası (http://www.tcmb.gov.tr/), Erişim tarihi: 20.03.2018

Yalta, M.N., 2011. Analyzing energy consumption and GDP nexus using maximum entropy bootstrap: The case of Turkey. Energy Economics, 33, 453-460.

Yanar, R. ve Kerimoğlu, G., 2011. Türkiye'de Enerji Tüketimi, Ekonomik Büyüme Ve Cari Açık İlişkisi. Ekonomi Bilimleri Dergisi, 2(3), 191-201. 
Efeoğlu R., Pehlivan C.. (2018), “Türkiye'de Enerji Tüketimi ve Cari Açı̆̆ın Ekonomik Büyüme Üzerine Etkileri” Politik Ekonomik Kuram, Cilt 2(1)

Yaprakl1, S. ve Yurttançıkmaz, Z.Ç., 2012. Elektrik Tüketimi İle Ekonomik Büyüme Arasındaki Nedensellik: Türkiye Üzerine Ekonometrik Bir Analiz. C.Ü. İktisadi ve İdari Bilimler Dergisi, 2(13), 195-215.

Zapata, H. ve Rambaldi, A., 1997. Monte Carlo Evidence on Cointegration and Causation, Oxford Bulletin of Economics and Statistics, 59, 285-298. 